\title{
An Ontology for Licensing Public Transport Services
}

\author{
Guillermina Cledou and Luis Barbosa \\ HASLab INESCTEC \& Universidade do Minho \\ Braga, Portugal \\ mgc@inesctec.pt, Isb@di.uminho.pt
}

\begin{abstract}
By 2050 it is expected that $66 \%$ of the world population will reside in cities, compared to $54 \%$ in 2014. One particular challenge associated to urban population growth refers to transportation systems, and as an approach to face it, governments are investing significant efforts enhancing public transport services. An important aspect of public transport is ensuring that licensing of such services fulfill existing government regulations. Due to the differences in government regulations, and to the difficulties in ensuring the fulfillment of their specific features, many local governments develop tailored Information and Communication Technology (ICT) solutions to automate the licensing of public transport services. In this paper we propose an ontology for licensing such services following the REFSENO methodology. In particular, the ontology captures common concepts involved in the application and processing stage of licensing public bus passenger services. The main contribution of the proposed ontology is to define a common vocabulary to share knowledge between domain experts and software engineers, and to support the definition of a software product line for families of public transport licensing services.
\end{abstract}

\section{CCS Concepts}

- Information systems Ontologies - Software and its engineering $\sim$ Software product lines.

\section{Keywords}

Ontologies; Public Transport Licensing Services; Software Product Lines;

\section{INTRODUCTION}

In $2014,54 \%$ of the world's population was living in urban areas, and such percentage is expected to grow by 2050 to $66 \%$ [34]. As the number of residents in urban areas continues to increase, governments need to address serious sustainable developmentrelated challenges; e.g. improving city infrastructure for increasing demand of energy, access to safe water, environmental footprint, and transportation, among many others. For example, regarding transportation, it is estimated that road transport consumes about $70 \%$ of the energy used in the world transport system and only road passenger transport accounts for $50 \%$ of this energy consumption [9]. According to [33], the transport sector is responsible for $80 \%$ of air pollution in developing countries. Additionally, increases in vehicle ownership and lack of adequate

Permission to make digital or hard copies of all or part of this work for personal or classroom use is granted without fee provided that copies are not made or distributed for profit or commercial advantage and that copies bear this notice and the full citation on the first page. To copy otherwise, or republish, to post on servers or to redistribute to lists, requires prior specific permission and/or a fee.

Conference'10, Month 1-2, 2010, City, State, Country.

Copyright 2010 ACM 1-58113-000-0/00/0010 ...\$15.00. traffic management contribute to traffic congestions increasing commuting time and deteriorating the moving experience of city dwellers.

Addressing the challenges described above, governments develop public transport systems as a reliable way of contributing to sustainable transportation and other social challenges related to urbanization. Doing so, they contribute to [33]: 1) reducing energy use and emissions; 2) alleviating congestions, and consequently 3 ) increasing productivity and 4) relieving air pollution; 5) improving access and mobility; 6) creating jobs; and 7) relieving alienation of the urban poor.

Besides developing the necessary road infrastructure, an important aspect of public transport systems is ensuring that licensing of public transport services - e.g. licenses to operate passenger transport services, and licenses for vehicles to carry passengers, among others; fulfill existing government regulations. Due to the differences in government regulations, and to the difficulties in ensuring the fulfillment of their specific features, many local governments develop tailored Information and Communication Technology (ICT) solutions to automate the licensing of public transport services; while others less resourceful rely on paperbased in person interactions for delivering such services.

Contributing to the development of a generic solution for licensing public transport services, this paper introduces an ontology for licensing public bus passenger services. The aim of the ontology is to serve as: 1) a tool for transport authorities and software developers for defining a common vocabulary to share knowledge and have a common understanding between domain experts and software engineers; 2) a tool for guiding the transition from a public service delivered through traditional channels (face-to-face interactions) to supporting the delivery through electronic channels; and 3) a valuable component supporting domain-specific software development; i.e. supporting the development of a software product line (SPL) to enable the automatic generation of families of licensing public transport services, identifying common domain features, and guiding the specification and configuration of specific licensing services implementations for different local governments.

The proposed ontology captures common concepts - e.g. actors, supporting documents, and attributes required in the application and processing stage of three examples licenses: 1) a license to operate passenger services, 2) a license to provide a bus passenger service across specified pick up and set down points following a predefined schedule and a fare scheme, and 3) a license for each vehicle used to transport passengers.

Given that the intended use of the ontology is to support automatic software development, we decided to use the REFSENO methodology [31]- a representation formalism for building software engineering ontologies. One important advantage of REFSENO is that it structures knowledge in the form of tables, simplifying the learning curve for developers and increasing readability for users of the ontology. 
The rest of this paper is structured as follows. Section 2 presents the research methodology. Section 3 discusses some related work. Section 4 defines the domain scope considered by the proposed; while Section 5 introduces some background on ontologies. Section 6 explains the proposed ontology. Section 7 discusses usage scenarios and limitations. Finally, Section 8 summarizes conclusions and discusses future work.

\section{RESEARCH METHODOLOGY}

The research methodology comprises four activities explained below. The methodology is illustrated in Figure 1.

1) Literature Review - 1) assessing existing related work on the development of electronic licensing services, and on the use of ontologies to support Electronic Government (eGovernment), 2) identifying a family of licensing public transport services to serve as case study, sharing common vocabulary and functionality and amendable to be delivered through similar business processes.

2) Domain Analysis - to understand the licensing public transport service domain, in particular by studying government guidelines and application forms from two case studies of licensing public bus passenger services, as explained in Section 4. The domain analysis produced UML Class and Activity Diagrams, contributing to identifying main domain elements and business processes used during the licensing application and processing stages.

3) Ontology Analysis - studying methodologies and tools used to define ontologies and selecting a suitable approach to define an ontology for licensing public transport services.

4) Ontology Definition - defining an ontology for licensing public transport services able to capture common vocabulary of the various services in the family analyzed in 2) and using methodologies and tools selected from 3 ).

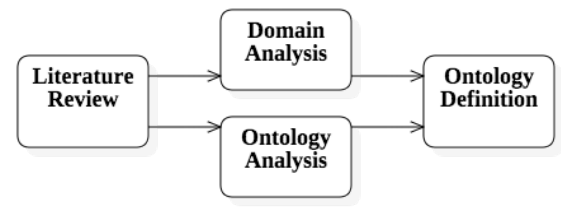

Figure 1: Research Methodology

\section{RELATED WORK}

This section discusses related work on the development of electronic licensing services (Section 3.1) and on ontologies to support e-Government (Section 3.2).

\subsection{Electronic licensing services}

Regarding the development of electronic licensing services, only few relevant studies have been found in the literature. In [27], the authors propose a composite domain framework for rapid development of electronic public services (EPS). It includes frameworks for building the front office and back office part of an EPS. In particular, they illustrate the application of the framework by developing an electronic licensing service by instantiating the proposed frameworks. A software infrastructure and a software process is proposed in [16] for the rapid development of EPS and its application is shown in [15] through a case study focused on delivering licensing services. In [1], the authors propose an interoperability integration framework to align the organizational structures and processes of different government agencies and to provide integrated public services. In particular, the authors illustrate the approach by integrating three related and required EPS for the provision of a tourism agency license.

\subsection{Ontologies to support e-Government}

Many studies in the literature use ontology-based approaches to support e-Government in diverse ways. In [30] the authors proposed ontologies as a basis for a Model Driven Architecture approach to e-Government. The approach facilitates to semantically model every public service specifying references to the required input elements and constrains on the input data that can later be evaluated by semantic reasoners. Such specifications enable the automatic creation of (web) forms and interactive plausibility checks of the data gathered from the user. The input data can be transformed into a common data interchange standard format to facilitate the exchange of electronic documents between government agencies. A similar work is proposed in [4] where ontologies are used again to semantically model services and to define data structures used in the services. Later the models are used to automatically define user interfaces for collecting data. The data structure serves once more as an intra and inter communication standard between government agencies to exchange information. In [24] the authors propose and ontologybased framework for automatic composition of web services; while in [25], ontologies are used to automatically generate web services customized to senior citizens' needs and government program laws and regulations. The ontology provides a conceptual template for government agencies to describe their operations. In [2] the authors propose an ontology-based decision framework for managing changes in e-government services. The approach uses formal methods to attain consistency when changes are discovered. In addition, it enables developers to respond to changes by using design rational knowledge. Finally, [23] introduces an ontology to formalize the Government Chief Information Officer (GCIO) function.

\section{DOMAIN SCOPE}

To understand the domain and define the grounds for building the ontology we selected and studied two case studies of licensing public bus passenger services: 1) from Ireland [21, 22, 35], and 2) from Portugal $[6,19,20]$. We analyzed government guidelines and application forms from both case studies with the purpose of identifying: 1) licenses required for the provision of public bus transport services, 2) documentation required for the application of each license, 3) application process activities, and 4) entities involved in the provision of the licensing services.

The ontology defined in Section 6 is based on the results from the previous analysis. All concepts, attributes, and relationships were defined based on the information extracted from the guidelines and application forms publicly available in official government portals from Ireland [21, 22, 35] and Portugal [6, 19, 20].

In particular, the proposed ontology considers information related to three types of licenses required for providing public bus passenger services as identified from both case studies: 1) a license to operate passenger services, 2) a license to provide a public bus passenger service across specified pick up and set down points following a predefine schedule and a fare scheme, and 3) a license for each vehicle used to transport passengers.

\section{ONTOLOGIES}

Several definitions of ontology are available in the literature: 1) it is "an explicit specification of a conceptualization" [12]; 2) it is a formal explicit description of concepts in a domain of discourse, 
properties of each concept describing various features and attributes of the concept, and restrictions on these properties, which all together in conjunction with a set of instances of the concepts constitutes a knowledge base [26]; 3) it is "a representational artifact, comprising a taxonomy as proper part, whose representations are intended to designate some combination of universals, and to define classes, and certain relations between them" [3].

Based on the definitions above, it can be concluded than an ontology is a formal mechanism to represent concepts (possibly of a particular domain) and their relationships, providing a common vocabulary of the domain. Thus, ontologies are an instrument to standardize knowledge, providing several advantages [3]: 1) promoting greater consistency in the description of data, 2) enabling the creation of software tools for mining valuable knowledge from different sources, 3) promoting accumulation of information, 4) facilitating information sharing, and others.

To leverage on these advantages, an ontology itself must be developed using formal mechanism and has to be maintained over time as the domain it represents evolves [3]. For this purpose, several methodologies exist in the literature to guide the development of new ontologies. Below we briefly introduce some of these approaches. More comprehensive overviews of methodologies and their comparisons can be found in [22, 23].

- Grüninger and Fox - The methodology proposed in [13] involves four steps: 1) defining a set of questions that the ontology should be able to answer, i.e., these are the ontology's requirements; 2) defining the concepts that will be part of the ontology, their properties and relationships; 3) formally specifying definitions and constrains of the concepts identified using first order logic as formalism; and 4) implementing the specifications in Prolog (a language based in first-order predicate calculus). It is possible to test the competency of the ontology by proving completeness theorems based on formulating questions in the first step.

- METHONTOLOGY - It provides a comprehensive approach presenting the set of activities that are part of the ontology development process, the life cycle of an ontology, and a method to build ontologies from scratch [11]. For each activity of the development process, METHONTOLOGY provides guidelines, considerations, and a set of deliverables that should be produced. The life cycle identifies the various stages through which an ontology evolves and establishes when each activity should be carried out.

- Representation Formalism for Software Engineering Ontologies (REFSENO) - It is a representation formalism to model the structure of an experience base for software engineering. REFSENO is in fact an improved adaptation of METHONTOLOGY. The motivation behind this formalism is to build ontologies to [31]: 1) collect experiences from software projects; 2) capture and reuse explicit software development know-how; 3) provide support for software organizations in collecting, packaging, validating and reusing experiences; and 4) formalize informal knowledge. The methodology suggests a process model to develop ontologies using a set of pre-defined tables to structure knowledge, including tables for defining: 1) a glossary of concepts, 2) attributes of the concepts, 3) relationships among concepts, and 4) instances of the concepts to capture experience. The main advantage of REFSENO over other formalisms is 1) its support for similarity-based retrieval knowledge, and 2) a clear distinction between stable knowledge (concepts) and example knowledge (experience).

A study [22] documents a comparison between various ontology methodologies, including, METHONTOLOGY and Grüninger and Fox. It concludes that the former is the most mature approach, since other ontologies, such as the latter, do not specify a comprehensive life cycle, lack support to maintain and adapt the ontology over time, and do not provide guidelines to perform each of the steps described in the methodologies.

Given the nature of this work and the fact that REFSENO is an improved adaptation of METHONTOLOGY we believe that REFSENO is better suited for this work. Other reasons in support of REFSENO include: 1) it is oriented to support software engineering ontologies, and 2) it provides and easy way to structure knowledge using tables, thus it does not require to learn complex specification languages.

\section{PROPOSED ONTOLOGY}

This section describes each of the steps applied to build the public transport licensing service ontology. Following REFSENO methodology, the process model comprises [31]: 1) ontology specification; 2) definition of a glossary of concepts; 3) identification of relationships between concepts; 4) identification and definition of terminal attributes for each concept; 5) identification and definition of nonterminal attributes for each concept; 6) completeness check of all concept attributes tables; and 7) definition of instances of the ontology, if any. The following sections elaborate on each of the steps and illustrate some of the tables developed during this process.

\subsection{Ontology specification}

The first step comprises specifying the ontology. This includes information about the domain being modeled, the purpose of the ontology, its scope, and relevant information regarding its authors, development date, and other data. Table 1 defines the ontology specification.

Table 1: Ontology specification

\begin{tabular}{|c|c|}
\hline Domain & Licensing Public Transport Services \\
\hline Date & November, 2015 \\
\hline Conceptualized by & Guillermina Cledou, Elsa Estevez, Luis Barbosa \\
\hline Purpose & $\begin{array}{l}\text { To model required information when providing and } \\
\text { requesting public transport licensing services in } \\
\text { order to: 1) facilitate the transition from service } \\
\text { delivery through traditional channels to electronic } \\
\text { channels, 2) serve as a tool defining a common } \\
\text { vocabulary to share knowledge and have a common } \\
\text { understanding between domain experts and software } \\
\text { engineers, and 3) be used as a supporting tool for the } \\
\text { development of a SPL for the modeled domain. }\end{array}$ \\
\hline Level of formality & Semi-formal (REFSENO) \\
\hline Scope & $\begin{array}{l}\text { list of concepts: } \\
\text { Additional Information, Appeal, Application } \\
\text { Payment Receipt, Application Process Criteria, } \\
\text { Approved License, Bus Stop Approval, Business } \\
\text { Stakeholder, Criminal Record Certificate, Day } \\
\text { Specific Schedule, Eligibility Criteria, Existing } \\
\text { License, Financial Capability Evidence, Individual } \\
\text { Stakeholder, Journey, Legal Person Card, License } \\
\text { Application, License Application Supporting } \\
\text { Documents, License Decision, License for } \\
\text { Passenger Transport, License for Transport } \\
\text { Operator, License for Vehicle, Life Cycle Stage per } \\
\text { License, Livery, Map, Market Information, } \\
\text { Ownership Certificate, Registration Certificate, } \\
\text { Regular Schedule, Rejected License, Request, Road }\end{array}$ \\
\hline
\end{tabular}




\begin{tabular}{l|l}
\hline & $\begin{array}{l}\text { Transit-able Certificate, Route, Route Existing } \\
\text { License, Route Supporting Documents, Schedule, } \\
\text { Stakeholder, Stakeholder Supporting Documents, } \\
\text { Stop, Subcontracting Contract, Tax Clearance }\end{array}$ \\
& $\begin{array}{l}\text { Evidence, Transport License Service, Vehicle, } \\
\text { Vehicle Existing License, Vehicle Inspection }\end{array}$ \\
Certificate, Vehicle Insurance, Vehicle Supporting \\
Documents \\
Instances: none. \\
\hline knource of & $\begin{array}{l}\text { Guidelines and forms from Portugal's transport } \\
\text { related licensing services [7, 17, 18] } \\
\text { Guidelines and forms from Ireland's transport } \\
\text { related licensing Services [19, 20, 32] }\end{array}$ \\
\hline
\end{tabular}

\subsection{Glossary of concepts}

The second step consists of defining all concepts identified in the scope of the ontology, as defined during the specification step. For this purpose the methodology proposes a table listing all concepts alphabetically with their definitions. Table 2 presents the glossary of concepts for some of the main concepts in the public transport licensing service ontology.

Table 2: Glossary of Concepts

\begin{tabular}{|c|c|}
\hline Name & Description \\
\hline $\begin{array}{l}\text { Application } \\
\text { Processing Criteria }\end{array}$ & $\begin{array}{l}\text { It specifies a set of criteria for modeling the } \\
\text { application processing workflow. }\end{array}$ \\
\hline Approved License & The outcome of an accepted license application. \\
\hline License Application & $\begin{array}{l}\text { It represents all relevant information submitted in } \\
\text { request of a license. }\end{array}$ \\
\hline $\begin{array}{l}\text { License Application } \\
\text { Supporting } \\
\text { Document }\end{array}$ & $\begin{array}{l}\text { Documentation that can be requested by the } \\
\text { corresponding authorities to complete a valid } \\
\text { application. }\end{array}$ \\
\hline License Decision & It represents the outcome of a license application. \\
\hline $\begin{array}{l}\text { License for } \\
\text { Passenger Transport }\end{array}$ & $\begin{array}{l}\text { A license that enables the holder to provide a public } \\
\text { bus passenger transport service across specified pick } \\
\text { up/set down points following a predefined schedule } \\
\text { and fare scheme. }\end{array}$ \\
\hline $\begin{array}{l}\text { License for } \\
\text { Transport Operator }\end{array}$ & $\begin{array}{l}\text { A license that enables the holder to operate hire and } \\
\text { reward passenger transport services. }\end{array}$ \\
\hline License for Vehicle & $\begin{array}{l}\text { A license that enables a vehicle to be used for } \\
\text { transporting passenger for hire and reward. }\end{array}$ \\
\hline $\begin{array}{l}\text { Life Cycle Stage per } \\
\text { License }\end{array}$ & $\begin{array}{l}\text { It defines possible status of the application, such as } \\
\text { request, renew, amend, cancel, transfer, and revoke. }\end{array}$ \\
\hline Rejected License & The outcome of a rejected license application. \\
\hline Stakeholder & $\begin{array}{l}\text { It represents a party involved in the process of } \\
\text { requesting a license. }\end{array}$ \\
\hline $\begin{array}{l}\text { Stakeholder } \\
\text { Supporting } \\
\text { Document }\end{array}$ & $\begin{array}{l}\text { Stakeholder's official documentation that can be } \\
\text { requested by the corresponding authorities to make a } \\
\text { valid application. }\end{array}$ \\
\hline $\begin{array}{l}\text { Transport License } \\
\text { Service }\end{array}$ & $\begin{array}{l}\text { A service providing the necessary functionality for } \\
\text { applying, processing, and issuing a particular type of } \\
\text { transport license. }\end{array}$ \\
\hline
\end{tabular}

\subsection{Concepts relationships}

The third step consists of identifying semantic relationships between concepts. For this purpose, the methodology proposes a graphical notation using boxes for the concepts and edges between concepts to express their relationships - this constitutes a graphical representation of the ontology. The edges can be annotated with the kind of relation they represent - i.e. "is-a", "instance-of", "has-decomposition", and "has-parts"; and the cardinality at both ends. The predefined relations and their notation can be seen in Figure 2 - relations read from left to right.

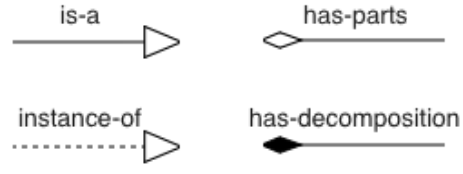

Figure 2: Predefine Relation Types

Each time a new kind of relationship is used it is necessary to define it in a supplementary table. For each relation, the table defines: name, reversed name (enabling to reading relationships both ways), purpose of the relation, the structure the relationship establishes on instances of the concepts, and properties of the relationship. Table 3 defines the new relations identified for the proposed ontology, following REFSENO methodology.

Table 3: Relationships

\begin{tabular}{l|l|l|l|l}
\hline Name & $\begin{array}{l}\text { Reverse } \\
\text { Name }\end{array}$ & Purpose & Structure & Properties \\
\hline allows & $\begin{array}{l}\text { allowed- } \\
\text { by }\end{array}$ & $\begin{array}{l}\text { The Bus Stop Approval } \\
\text { document allows the pick up } \\
\text { and set down of passengers } \\
\text { in a Stop of a particular } \\
\text { route. The same Stop is } \\
\text { required to be approved for } \\
\text { different routes. }\end{array}$ & DAG* & Transitivity \\
\hline requests & $\begin{array}{l}\text { requested- } \\
\text { by }\end{array}$ & $\begin{array}{l}\text { License Application requests } \\
\text { a particular type of licensing } \\
\text { service at a given Life Cycle } \\
\text { Stage per License. Given the } \\
\text { state, applications must } \\
\text { conform to the application's } \\
\text { pre-defined requirements for } \\
\text { each license. }\end{array}$ & DAG* & Transitivity \\
\hline provides & provided- \\
by & $\begin{array}{l}\text { A Government Authority } \\
\text { provides Transport Licensing } \\
\text { Services and is responsible } \\
\text { for authorizing and } \\
\text { regulating the issuing of } \\
\text { licenses as well as ensuring } \\
\text { accountability of the decision } \\
\text { process. }\end{array}$ & DAG* & Transitivity & \\
\hline
\end{tabular}

*DAG $=$ Directed Acyclic Graph

A graphical representation of the ontology for transport licensing services showing each concept and their relationships is depicted in Figure 3. The essence of the concepts and the relationships defined in the ontology are summarized below.

A Government Authority can provide various Transport Licensing Services. Each license service corresponds to one type of license (for example but not limited to, Passenger Transport, Transport Operator, and Vehicle) and provides functionality to one or more types of applications (Life Cycle Stage per License) for that type of license - e.g., request, renew, amend, cancel, etc. Each type of application for a particular license implements: 1) eligibility criteria that will support authorities in deciding whether to grant the license or not - e.g., suitability of applicant, interference with other granted licenses, etc. and 2) application processing criteria that defines procedural requirements for authorities when processing the applications and procedural requirements for applicants when submitting applications - e.g., deadlines for processing applications, whether resubmission of incomplete applications are allowed, if a fee is required, etc.

Each License Application involves various stakeholders, either individuals or businesses, such as the applicant (mandatory), members of the business in the case the applicant is a business, and subcontractors if the applicant intends to subcontract part of 
the future license obligations to other stakeholder. A license application may require various supporting documents for each stakeholder. The type of documents required will vary on the type of license, the type of the application and the actual implementation of the licensing services. In the proposed ontology, we define typical documents requested from stakeholders that were identified from the case studies: legal person card and registration certificate (businesses only), tax clearance evidence, criminal record certificate, subcontracting contract, financial capability evidence, and other exiting licenses.

In addition, a license application requires different supporting documents that are related to the application itself and the type of application. As before, the required documents will vary depending on the type of license and type of application. Here we define typical documents required for the three types of licenses identified from the case studies: a formal request, proof of application payment, market information that can support the application, vehicle related information, route related information, and any additional information the applicant considers relevant.

Vehicle related information includes: information about the vehicles it self, intended livery for vehicles of a passenger transport service, and supporting document for the vehicles such certificates of insurances and inspections, proof of ownership, certificate, and previous licenses involving the vehicle, if any.

Information related to a route is typically required when applying for a passenger transport license. This includes: inherent information about the intended route to serve, information about bus stops, detailed schedule, and supporting documents such as a map of the city highlighting the route and bus stops, previous licenses of the route, a certificate to attest that the route is transitable, and certificates of approval to pick up and set down passengers in each of the intended bus stops for the route.

Finally, a license application will result in a decision whether to accept or to reject the issuing of the license. In case the license application is rejected, the applicant may have the right to appeal such decision.

\subsection{Concept attribute table}

The fourth and fifth steps in the process model consist of identifying and defining terminal and nonterminal attributes for each of the concepts defined in the ontology. The methodology proposes a pre-defined table to capture such knowledge. The table is divided in two sections - concept related information, and attributes information. The former specifies the concept and its super-concept, if any. It is assumed that the concept inherits attributes from its super-concept. The latter specifies attribute information such as name, description, cardinality, type and whether it is mandatory or not. Both terminal and nonterminal attributes are defined in the concept table. However, for reasons of clarity and to respect the order in which the activities of each step are performed we present them here using two separate tables. The following sections introduce these activities and present some results from the proposed ontology. As mentioned in Section 4, attributes for each concept were extracted from guidelines and application forms from both case studies.

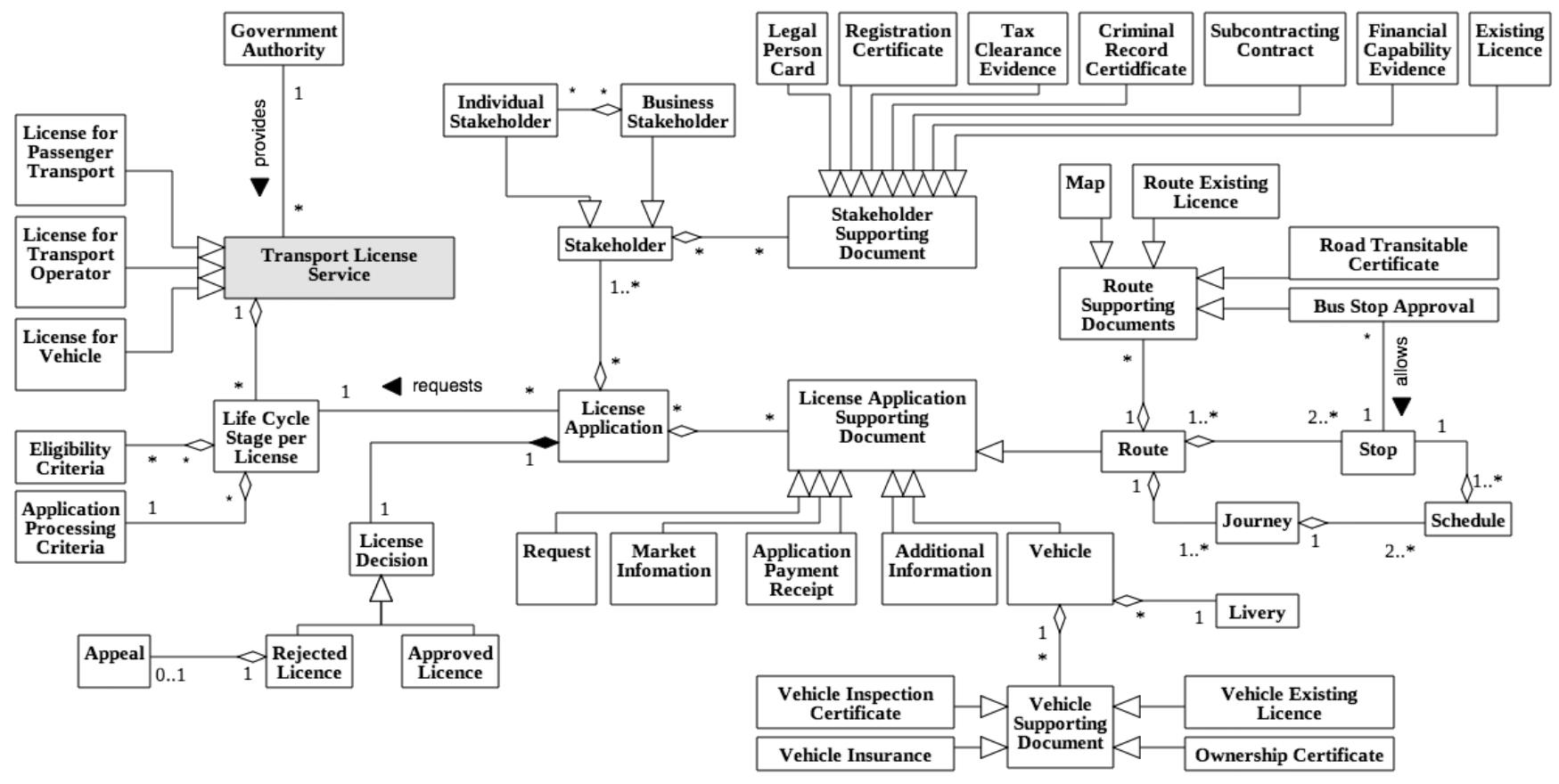

Figure 3: Transport Licensing Services Ontology

\subsubsection{Terminal attributes}

A terminal concept attribute serves to model how software engineering entities are specified for storage and retrieval. It can be seen as a property or a data element of a concept. Following the table structure introduced above, Table 4 illustrates various concept attributes tables for some of the main concepts identified in the ontology.

Table 4: Concept Attribute Table - Terminal Attributes

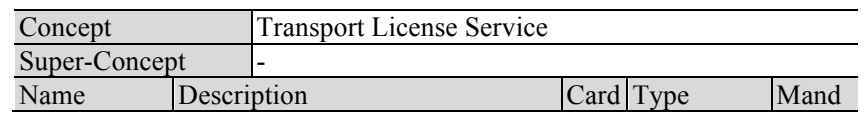




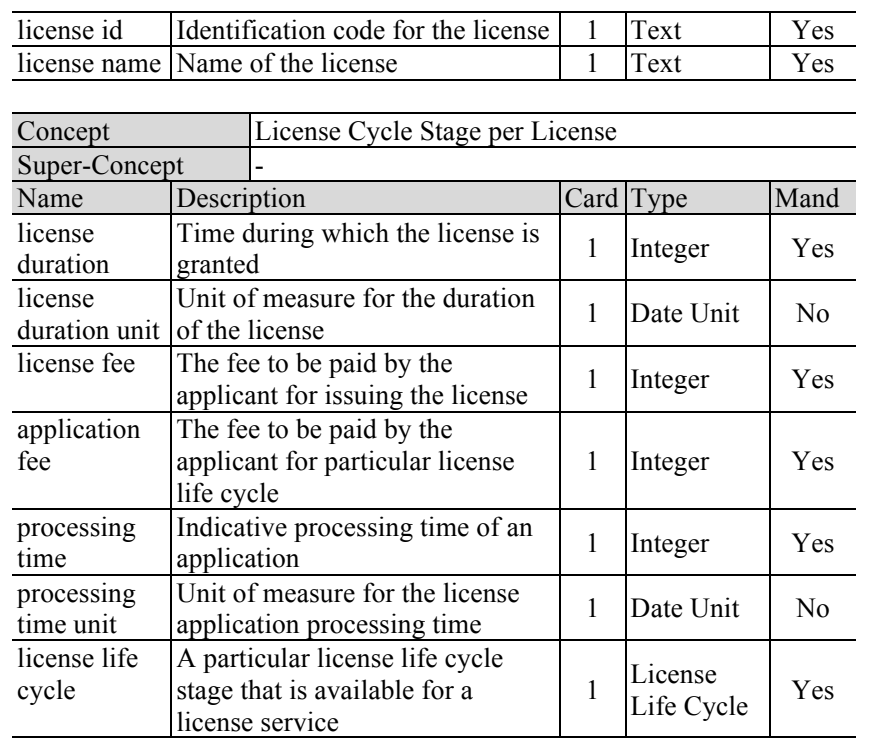

\begin{tabular}{l|l|c|l|c}
\hline Concept & \multicolumn{4}{l}{ License Application } \\
\hline Super-Concept & - & \multicolumn{3}{l}{} \\
\hline Name & Description & Card & Type & Mand \\
\hline id & $\begin{array}{l}\text { Identification code for a license } \\
\text { application }\end{array}$ & 1 & Integer & Yes \\
\hline $\begin{array}{l}\text { submission } \\
\text { date }\end{array}$ & $\begin{array}{l}\text { Date when the application is } \\
\text { submitted }\end{array}$ & 1 & Date & Yes \\
\hline $\begin{array}{l}\text { payment } \\
\text { method }\end{array}$ & $\begin{array}{l}\text { Type of payment method chosen } \\
\text { to pay for the application, if } \\
\text { applicable }\end{array}$ & 1 & $\begin{array}{l}\text { Payment } \\
\text { Method }\end{array}$ & No \\
\hline $\begin{array}{l}\text { application } \\
\text { stage }\end{array}$ & $\begin{array}{l}\text { Current stage in the application } \\
\text { processing life cycle }\end{array}$ & 1 & $\begin{array}{l}\text { Application } \\
\text { Life Cycle }\end{array}$ & Yes \\
\hline
\end{tabular}

\begin{tabular}{l|l|c|l|c}
\hline Concept & \multicolumn{4}{l}{ Stakeholder } \\
\hline Super-Concept & - & \multicolumn{3}{l}{} \\
\hline Name & Description & Card & Type & Mand \\
\hline id & $\begin{array}{l}\text { Identification code for a } \\
\text { stakeholder }\end{array}$ & 1 & Integer & Yes \\
\hline name & $\begin{array}{l}\text { Stakeholder's name - first, } \\
\text { middle and last name of a person } \\
\text { in the case of individuals, or } \\
\text { business name in the case of } \\
\text { businesses. }\end{array}$ & 1 & Text & Yes \\
\hline address & Stakeholder's primary address & 1 & Text & Yes \\
\hline phone & Stakeholder's phone number & 1 & Text & Yes \\
\hline e-mail & Stakeholder's e-mail address & 1 & Text & Yes \\
\hline city & City of the stakeholder's address & 1 & Text & Yes \\
\hline zip-code & $\begin{array}{l}\text { Zip-code of the stakeholder's } \\
\text { address }\end{array}$ & 1 & Text & Yes \\
\hline role & $\begin{array}{l}\text { Role of the stakeholder within the } \\
\text { application and licensing process }\end{array}$ & 1 & $\begin{array}{l}\text { Stakeholder } \\
\text { Role }\end{array}$ & Yes \\
\hline
\end{tabular}

\begin{tabular}{|c|c|c|c|c|c|}
\hline \multirow{2}{*}{\multicolumn{2}{|c|}{$\begin{array}{l}\text { Concept } \\
\text { Super-Concept } \\
\end{array}$}} & \multicolumn{4}{|l|}{ Business Stakeholder } \\
\hline & & Stakeholder & & & \\
\hline Name & \multicolumn{2}{|c|}{ Description } & Card & Type & Mand \\
\hline legal number & \multicolumn{2}{|c|}{ Number of the legal person } & 1 & Text & Yes \\
\hline business type & \multicolumn{2}{|c|}{ Type of business } & 1 & $\begin{array}{l}\text { Business } \\
\text { Type }\end{array}$ & Yes \\
\hline \multicolumn{2}{|l|}{ Concept } & \multicolumn{4}{|c|}{ Stakeholder Supporting Document } \\
\hline \multicolumn{2}{|l|}{ Super-Concept } & - & & & \\
\hline Name & \multicolumn{2}{|c|}{ Description } & Card & Type & Mand \\
\hline id & \multicolumn{2}{|c|}{$\begin{array}{l}\text { Identification code for a } \\
\text { document }\end{array}$} & 1 & Integer & Yes \\
\hline attachment & \multicolumn{2}{|c|}{$\begin{array}{l}\text { An attached copy of a required } \\
\text { document, if applicable }\end{array}$} & $*$ & Attachment & No \\
\hline
\end{tabular}

\begin{tabular}{l|l|c|l|c}
\hline authenticated & $\begin{array}{l}\text { Whether the attached document } \\
\text { has been approved as valid or not }\end{array}$ & 1 & Boolean & Yes \\
\hline
\end{tabular}

\begin{tabular}{l|l|l|l|l}
\hline Concept & \multicolumn{5}{l}{ Tax Clearance Evidence } & \multicolumn{3}{l}{} \\
\hline Super-Concept & Stakeholder Supporting Document & \\
\hline Name & Description & Card & Type & Mand \\
\hline tax number & Tax identification number & 1 & Text & Yes \\
\hline issuing date & Date of issue of the tax evidence & 1 & Date & Yes \\
\hline issuing entity & Entity that issued the certificate & 1 & Text & Yes \\
\hline cleared & $\begin{array}{l}\text { Whether the evidence proves the } \\
\text { tax clearance for the } \\
\text { corresponding stakeholder or not }\end{array}$ & 1 & Boolean & Yes \\
\hline
\end{tabular}

Each time a new type of terminal attribute is identified, it shall be defined in a supplementary table. REFSENO contains some predefined types including: Boolean, Text, Integer, Date, Symbol (symbols ordered alphabetically), and OrderedSymbol (symbols ordered from lowest to highest). For simplicity, we consider the type "Attachment" (attribute of Stakeholder Supporting Document) as a predefine type. This type represents an attached digital file. Table 5 shows the type's definitions for each new attribute type identified in Table 4. Each type definition includes the name of the type, the super-type, and the range of possible values for attributes of this type. The legend DYNAMIC following the range definition informs that the range of possible values can be extended.

If the types table includes declarations of symbol types it is necessary to define a glossary of symbols including a narrative definition for each possible value. Table 6 shows the symbol definition for some of the symbols types identified in Table 5.

\section{Table 5: Types}

\begin{tabular}{l|l|l}
\hline Name & Super-Type & Value Range \\
\hline Date Unit & OrderedSymbol & "Day", "Week", "Month", "Year" \\
\hline License Life Cycle & OrderedSymbol & $\begin{array}{l}\text { "Request", "Renewal", } \\
\text { "Transference", "Amendment", } \\
\text { "Cancelation", "Revocation" }\end{array}$ \\
\hline $\begin{array}{l}\text { Application Life } \\
\text { Cycle }\end{array}$ & OrderedSymbol & $\begin{array}{l}\text { "Submitted", "Processing", } \\
\text { "Rejected", "Accepted" } \\
\text { DYNAMIC }\end{array}$ \\
\hline Payment Method & Symbol & $\begin{array}{l}\text { "Card", "Cash", "Cheque", } \\
\text { "Postal Order", DYNAMIC }\end{array}$ \\
\hline Stakeholder Role & Symbol & $\begin{array}{l}\text { "Applicant", "Business Member", } \\
\text { "Subcontractor", DYNAMIC }\end{array}$ \\
\hline Business Type & Symbol & $\begin{array}{l}\text { "Company","Cooperative", } \\
\text { "Partnership" "Sole } \\
\text { Trader"DYNAMIC }\end{array}$ \\
\hline
\end{tabular}

Table 6: Glossary of Symbols

\begin{tabular}{l|l|l}
\hline Type & Symbol & Description \\
\hline License Life Cycle & Request & Request for a new license \\
\cline { 2 - 3 } & Renewal & $\begin{array}{l}\text { Request to renew an existing } \\
\text { license }\end{array}$ \\
\cline { 2 - 3 } & Transference & $\begin{array}{l}\text { Request to transfer an existing } \\
\text { license from one individual or } \\
\text { business to another }\end{array}$ \\
\cline { 2 - 3 } & Amendment & $\begin{array}{l}\text { Request to make changes to some } \\
\text { of the terms and conditions of an } \\
\text { existing license }\end{array}$ \\
\cline { 2 - 3 } & Cancelation & $\begin{array}{l}\text { Request to cancel the validity of } \\
\text { an existing license }\end{array}$ \\
\cline { 2 - 3 } & Revocation & $\begin{array}{l}\text { Request to withdraw an existing } \\
\text { valid license }\end{array}$ \\
\hline Stakeholder Role & Business Member & A person that is member of or \\
\hline
\end{tabular}




\begin{tabular}{|l|l}
\hline & related to a business stakeholder \\
\hline Subcontractor & $\begin{array}{l}\text { A stakeholder that posses a } \\
\text { required license and is } \\
\text { subcontracted to perform the } \\
\text { obligations related to the license }\end{array}$ \\
\hline Applicant & $\begin{array}{l}\text { A stakeholder that is the main } \\
\text { responsible for the application } \\
\text { process and the beneficiary of the } \\
\text { license if granted }\end{array}$ \\
\hline
\end{tabular}

\subsubsection{Nonterminal attributes}

A nonterminal attribute models how a particular software engineering entity is related to other software engineering entities. It can be seen as an association to other nonterminal concept. Nonterminal attributes of the predefined kind "is-a" are not represented explicitly in the table since such relationship is represented through the declaration of the super-concept. Following the table structure introduced in the previous section, Table 7 illustrates the concept attribute tables with nonterminal attributes for the concepts defined in Table 4.

Table 7: Concept Attribute Table - Nonterminal Attributes

\begin{tabular}{|c|c|c|c|c|}
\hline \multirow{2}{*}{$\begin{array}{l}\text { Concept } \\
\text { Super-Concep }\end{array}$} & \multicolumn{4}{|c|}{ Transport License Service } \\
\hline & - & & & \\
\hline Name & Description & Card & Type & Mand \\
\hline life cycle & $\begin{array}{l}\text { Stages in the license life } \\
\text { cycle that the license service } \\
\text { supports and provides } \\
\text { functionality for }\end{array}$ & * & $\begin{array}{l}\text { has-parts[Life } \\
\text { Cycle Stage per } \\
\text { License].[licens } \\
\text { e service] }\end{array}$ & Yes \\
\hline $\begin{array}{l}\text { responsible } \\
\text { agency }\end{array}$ & $\begin{array}{l}\text { Government agency } \\
\text { responsible for the provision } \\
\text { of the licensing service }\end{array}$ & 1 & $\begin{array}{l}\text { part- } \\
\text { of[Government } \\
\text { Agency].[licensi } \\
\text { ng services] }\end{array}$ & Yes \\
\hline
\end{tabular}

\begin{tabular}{|c|c|c|c|c|}
\hline \multirow{2}{*}{$\begin{array}{l}\text { Concept } \\
\text { Super-Concept }\end{array}$} & \multicolumn{4}{|c|}{ License Cycle Stage per License } \\
\hline & $\mathrm{pt}$ & & & \\
\hline Name & Description & Card & Type & Mand \\
\hline $\begin{array}{l}\text { license } \\
\text { service }\end{array}$ & $\begin{array}{l}\text { A particular type of transport } \\
\text { license service for the license } \\
\text { life cycle stage available }\end{array}$ & 1 & $\begin{array}{l}\text { part- } \\
\text { of[Transport } \\
\text { License } \\
\text { Service].[life } \\
\text { cycle] }\end{array}$ & Yes \\
\hline $\begin{array}{l}\text { eligibility } \\
\text { criteria }\end{array}$ & $\begin{array}{l}\text { Eligibility criteria associated } \\
\text { with a particular life cycle } \\
\text { stage of a transport license } \\
\text { service to support the } \\
\text { decision-making when } \\
\text { processing an application }\end{array}$ & * & $\begin{array}{l}\text { has- } \\
\text { parts[Eligibility } \\
\text { Criteria].[licens } \\
\text { e types] }\end{array}$ & Yes \\
\hline $\begin{array}{l}\text { application } \\
\text { processing } \\
\text { criteria }\end{array}$ & $\begin{array}{l}\text { Application processing } \\
\text { criteria to be considered when } \\
\text { implementing the transport } \\
\text { license application service }\end{array}$ & 1 & $\begin{array}{l}\text { has- } \\
\text { parts[Applicatio } \\
\text { n Processing } \\
\text { Criteria].[licens } \\
\text { e types] }\end{array}$ & No \\
\hline applications & $\begin{array}{l}\text { Applications made to request } \\
\text { this particular stage and } \\
\text { license type }\end{array}$ & $*$ & $\begin{array}{l}\text { requested- } \\
\text { by[License } \\
\text { Application].[ap } \\
\text { plication type] }\end{array}$ & Yes \\
\hline
\end{tabular}

\begin{tabular}{|c|c|c|c|c|}
\hline Concept & \multicolumn{4}{|l|}{ License Application } \\
\hline Super-Conc & - & & & \\
\hline Name & Description & Card & Type & Mand \\
\hline $\begin{array}{l}\text { license } \\
\text { decision }\end{array}$ & $\begin{array}{l}\text { Information related to the } \\
\text { decision whether to grant the } \\
\text { license or not }\end{array}$ & 1 & $\begin{array}{l}\text { has- } \\
\text { decomposition[ } \\
\text { License } \\
\text { Decision].[appli } \\
\text { cation] } \\
\end{array}$ & Yes \\
\hline $\begin{array}{l}\text { application } \\
\text { type }\end{array}$ & $\begin{array}{l}\text { The license type and the stage } \\
\text { in the license life cycle that }\end{array}$ & 1 & $\begin{array}{l}\text { requests[Life } \\
\text { Cycle Stage per }\end{array}$ & Yes \\
\hline
\end{tabular}

\begin{tabular}{l|l|l|l|l}
\hline & $\begin{array}{l}\text { the license application } \\
\text { currently holds }\end{array}$ & & $\begin{array}{l}\text { License].[applic } \\
\text { ations] }\end{array}$ & \\
\hline stakeholders & $\begin{array}{l}\text { Stakeholders involved in the } \\
\text { application of a license }\end{array}$ & $*$ & $\begin{array}{l}\text { has- } \\
\text { parts[Stakehold } \\
\text { er].[license } \\
\text { application] }\end{array}$ & Yes \\
\hline $\begin{array}{l}\text { supporting } \\
\text { documents }\end{array}$ & $\begin{array}{l}\text { Required documents } \\
\text { submitted to support the } \\
\text { application }\end{array}$ & $* \begin{array}{l}\text { has- } \\
\text { parts[License } \\
\text { Application } \\
\text { Supporting } \\
\text { Documents].[ap } \\
\text { plications] }\end{array}$ & Yes \\
\hline
\end{tabular}

\begin{tabular}{l|l|l|l|l}
\hline Concept & \multicolumn{4}{l}{ Stakeholder } \\
\hline Super-Concept & - & \multicolumn{3}{l}{} \\
\hline Name & Description & Card & Type & Mand \\
\hline $\begin{array}{l}\text { supporting } \\
\text { documents }\end{array}$ & $\begin{array}{l}\text { Required documents related } \\
\text { to the stakeholder that } \\
\text { support the application }\end{array}$ & $*$ & $\begin{array}{l}\text { has- } \\
\text { parts[Stakehold } \\
\text { er Supporting } \\
\text { Document].[sta } \\
\text { keholder] }\end{array}$ & Yes \\
\hline $\begin{array}{l}\text { license } \\
\text { application }\end{array}$ & $\begin{array}{l}\text { License applications in which } \\
\text { the stakeholder is involved }\end{array}$ & $*$ & $\begin{array}{l}\text { part-of[License } \\
\text { Application].[ap } \\
\text { plications] }\end{array}$ & Yes \\
\hline
\end{tabular}

\begin{tabular}{|c|c|c|c|c|c|}
\hline \multirow{2}{*}{\multicolumn{2}{|c|}{$\begin{array}{l}\text { Concept } \\
\text { Super-Concept }\end{array}$}} & \multicolumn{4}{|l|}{ Business Stakeholder } \\
\hline & & Stakeholder & & & \\
\hline Name & & ption & Card & Type & Mand \\
\hline $\begin{array}{l}\text { related } \\
\text { stakeholders }\end{array}$ & $\begin{array}{l}\text { Sta } \\
\text { bus } \\
\text { or 1 }\end{array}$ & $\begin{array}{l}\text { olders related to the } \\
\text { ss and their position in } \\
\text { tion to the business }\end{array}$ & $*$ & $\begin{array}{l}\text { has- } \\
\text { parts[Individual } \\
\text { Stakeholder].[re } \\
\text { lated business] }\end{array}$ & No \\
\hline
\end{tabular}

\begin{tabular}{l|l|l|l|l}
\hline Concept & \multicolumn{4}{l}{ Stakeholder Supporting Document } \\
\hline Super-Concept & \multicolumn{4}{ll}{} \\
\hline Name & Description & Card & Type & Mand \\
\hline stakeholder & $\begin{array}{l}\text { Stakeholder, owner of the } \\
\text { supporting documents }\end{array}$ & 1 & $\begin{array}{l}\text { part- } \\
\text { of[Stakeholder]. } \\
\text { [supporting } \\
\text { documents] }\end{array}$ & Yes \\
\hline
\end{tabular}

\subsection{Completeness check}

The sixth step in the process model involves checking the completeness of all concept attribute tables. As defined in Table 1, the purpose of the proposed ontology is to provide common vocabulary for the modeled domain with the intention of facilitating the generation of families of transport licensing services. This implies that the ontology will potentially be used to instantiate licensing public bus passenger services in very different environments - different countries with different laws and regulations. Therefore, the approach is only to define most elemental attributes for each concept. Each instantiation of the ontology can later define additional attributes and even additional concepts. Thus, completeness check is performed considering only elemental attributes that will likely be present in every instantiation of the concept. Based on this, each concept attribute table is complete with respect to the small set of such attributes.

\subsection{Instantiation}

The final step in building an ontology using REFSENO involves defining the instances specified in the ontology definition table (Table 1). For each instance, the methodology proposes a table containing an instance identification name, the concept associated to the instance, and the values for each of the attributes defined in the concept attribute table. Table 8 illustrates an instance of a Transport License Service using information collected from the Ireland Transport Licenses case study. In the example, license id 
and license name are terminal attributes, while responsible agency and life cycle are nonterminal. The nonterminal attributes indicate the reference name of the instance that is associated with this particular entry.

Table 8: Instantiation Example

\begin{tabular}{l|l}
\hline Concept & Transport License Service \\
\hline Instance & ireland_public_bus_passenger_service_license \\
\hline Name & Value \\
\hline license id & public_bus_passenger_service \\
\hline license name & Public Bus Passenger Service \\
\hline responsible agency & ireland_national_transport_authority \\
\hline life cycle & public_bus_passenger_service_regular_request \\
\hline
\end{tabular}

\section{DISCUSSION}

An advantage of building ontologies with REFSENO is that by construction it ensures: 1) completeness - in the sense that all relevant knowledge to instantiate a knowledge base is defined; and 2) consistency - in the sense that some consistency criteria have to be fulfilled during the construction such as: a) no concept, types, instances or attributes of a same concept have the same name, b) graphical representation of the nonterminal attributes and their relationships must match the tabular representation, etc. However, further validation of the ontology is required to ensure its adequacy for the modeled domain. As future work, we intend to use the ontology to model licensing services of new case studies, so to improve the ontology based on new knowledge.

The main aim of the proposed ontology is to facilitate the definition of generic models to support the automatic generation of a family of software applications for licensing public transport services; for example, by adopting SPL engineering methods and tools. There are several ways in which an ontology can be used to support SPL development and how SPL can be later used to support e-Government, as explained in the following sections. Additionally, by defining a common vocabulary, the ontology can serve other purposes: 1) facilitating the transition from paperbased delivery channels to electronic ones; 2) facilitating the integration of different licensing systems, and 3) improving government interoperability. The latter two are important because they facilitate information sharing between agencies enabling the delivery of one-stop, seamless services, and the implementation of the "tell-us-once" principle for reducing administrative burden [10].

As a limitation of the ontology, we highlight that the ontology itself does not define which supporting documents correspond to which type of license application. Further mechanisms related to SPL are necessary to specify this kind of restrictions in each particular instantiation of a licensing public transport service. We intend to address this limitation as we make progress towards using the ontology for the specified purpose in Table 1 .

The following subsections present some existing work in two areas - ontologies to support SPL and SPL to support the development of e-Government applications.

\subsection{Ontologies to support SPL}

There are several studies in the literature that explore various uses of ontologies to support SPL. In [14], the authors propose an approach to deal with inconsistencies in feature models (FM) due to changes. Based on an ontology-based formalization of feature models, they define constrains that FM must satisfy to be consistent, and develop a set of primitives to make changes in the
FM while analyzing the impact that these changes may have in the consistency of the FM. In [6], the authors propose an approach to facilitate verification of hard feature requirements such as platform characteristics and service requirements. It consists of an extension of an exiting approach that represents FM as ontologies. The use of ontologies facilitates the specification of hard requirements since they enable the specification of terminology common to the domain. Additionally, the authors provide an algorithm for automatically specialize FM based on the specification of provided services and platforms characteristics. In [29], the authors propose an ontological rule-based approach for analyzing dead and false optional features in FM as well as finding the causes for such errors and explaining the causes in natural language. The authors define a Feature Model Ontology to capture and exploit the semantic relationships between features, e.g., obtain features with both mandatory and optional constrains. By using first-order logic, it is possible to define rules for identifying such type of features and the causes. In [8], the authors present a product line approach to support scientist when selecting features in a Scientific SPL (SSPL). The approach uses an ontology in addition to a FM to overcome the lack of support FM have to represent domain semantic relationships between features - e.g., to represent that some optional feature is preferable to another, if some features were selected before. In [5] a semantic enrichment to SPL (Semantic SPL) is proposed. The approach consists of: 1) an automatic mapping from FM to an SSPL ontology specified in description logic notation; and 2) a model to guide the enrichment of the obtain ontology with semantic information that can not be expressed with FM - e.g., case studies covered by a feature, and recommended selection of features, among others.

\subsection{SPL to support e-Government}

Regarding SPL support for the development of e-government applications, only few studies have been found in the literature. In [21], the authors propose an SPL for generating front-end environments for an e-government context management system. In [28], the authors propose a method to generate personalized government documents using SPL. The approach takes advantage of the high level reuse of government documents.

\section{CONCLUSIONS}

This work presented an ontology for licensing public transport services, in particular for a family of licenses needed to provide public bus passenger services. After studying the domain, we defined the ontology following the methodology proposed by REFSENO, a representation formalism for building software engineering ontologies. The ontology defines basic domain knowledge required for the provision and application of electronic licensing services for following identified licenses: 1) operating passenger transport services, 2) providing an actual public bus service (serving a route), and 3) vehicles to transport passengers.

The main contribution of this work is the development of the ontology that defines common domain vocabulary. This can serve to: 1) facilitating the transition from traditional service delivery channels to electronic ones, 2) sharing knowledge and having a common understanding between domain experts and software engineers, and 3) supporting the development of a SPL for the modeled domain.

Limitations of the ontology were discussed in Section 7 and include: 1) the need to further validate the adequacy of the ontology for the modeled domain, and 2) the need for adopting an 
additional mechanism to model license specific requirements to guide the instantiation of particular license services.

Future work includes further research to 1) address the limitations of the ontology, and 2) to explore the use of the proposed ontology as an instrument to support the definition of a SPL for licensing public transport services.

\section{ACKNOWLEDGEMENT}

We thank Elsa Estevez for her valuable comments and help with the definition of the ontology.

The first author is supported by an Individual Doctoral Grant from FCT, reference number PD/BD/52238/2013.

\section{REFERENCES}

[1] Al-Husban, M. and Adams, C. 2014. Connected Services Delivery Framework: Towards Interoperable Government. Emerging Mobile and Web 2.0 Technologies for Connected E-Government. (2014), 50.

[2] Apostolou, D. et al. 2011. A collaborative decision framework for managing changes in e-Government services. Government Information Quarterly. 28, 1 (2011), 101-116.

[3] Arp, R. et al. 1989. Building Ontologies with Basic Formal Ontology.

[4] Barone, A. and Pietro, P. Di 2005. Ontologies to support the definition of the knowledge society. 2nd Italian Workshop on Semantic Web Applications and Perspectives (2005).

[5] Bosco Ferreira Filho, J. et al. 2012. An Approach for Semantic Enrichment of Software Product Lines. Proceedings of the 16th International Software Product Line Conference. II, (2012), 188-195.

[6] Bošković, M. et al. 2010. Automated Staged Configuration With Semantic Web Technologies. International Journal of Software Engineering and Knowledge Engineering. 20, 04 (2010), 459-484.

[7] Carreiras de Serviço Público - Guidelines and Forms: http://www.imtt.pt/sites/IMTT/Portugues/TransportesRod oviarios/TransportePublicoPassageiros/CarreirasServic oPublico/Paginas/CarreirasdeServiçoPublico.aspx.

Accessed: 2011-05-20.

[8] Costa, G.C.B. et al. 2013. PL-Science: A Scientific Software Product Line. Procedia Computer Science. 18, 0 (2013), 759-768.

[9] Deutsche Gesellschaft für Internationale Zusammenarbeit 2012. Urban Transport and Energy Efficiency. (2012).

[10] EY and Danish Technological Institute 2014. Study on eGovernment and the Reduction of Administrative Burden.

[11] Fernández-López, M. et al. 1997. Methontology: from ontological art towards ontological engineering. Assessment. SS-97-06, (1997), 33-40.

[12] Gruber, T.R. 1995. Toward principles for the design of ontologies used for knowledge sharing? International Journal of Human-Computer Studies.
[13] Grüninger, M. and Fox, M.S.. 1995. Methodology for the Design and Evaluation of Ontologies. International Joint Conference on Artificial Inteligence (IJCAI95), Workshop on Basic Ontological Issues in Knowledge Sharing. (1995), 1-10.

[14] Guo, J. et al. 2012. Consistency maintenance for evolving feature models. Expert Systems with Applications. 39, 5 (2012), 4987-4998.

[15] Janowski, T. et al. 2007. Rapid Development of Electronic Public Services - A Case Study in Electronic Licensing Service. 8th Annual International Digital Government Research Conference (2007), 292-293.

[16] Janowski, T. et al. Rapid Development of Electronic Public Services - Software Infrastructure and Software Process. 294-295.

[17] Licenciamento de Empresas - Guidelines and Forms http://www.imtt.pt/sites/IMTT/Portugues/TransportesRod oviarios/TransportePublicoPassageiros/LicenciamentoE mpresas/Paginas/LicenciamentoEmpresas.aspx. Accessed: 2011-05-20.

[18] Licenciamento de Veículos - Guidelines and Forms: http://www.imtt.pt/sites/IMTT/Portugues/TransportesRod oviarios/TransportePublicoPassageiros/LicenciamentoV eiculos/Paginas/LicenciamentoVeiculos.aspx. Accessed: 2015-11-01.

[19] Licensing of Large Public Service Vehicles Requirements:

http://www.garda.ie/Controller.aspx?Page $=100$. Accessed: 2011-05-20.

[20] Licensing of Public Bus Passenger Services - Guidelines and Forms: https://www.nationaltransport.ie/taxi-andbus-licensing/bus/. Accessed: 2015-11-01.

[21] Lima, V.M.A. de et al. 2014. A Generation Environment for Front-End Layer in e-Government Content Management Systems. (2014), 119-123.

[22] López, F. 1999. Overview Of Methodologies For Building Ontologies. Proceedings of the IJCAI99 Workshop on Ontologies and ProblemSolving Methods Lessons Learned and Future Trends CEUR Publications. 1999, 2 (1999), 1-13.

[23] Marcovecchio, I. et al. 2013. Government Chief Information Officer (GCIO) Ontology: A Tool to Formalize the GCIO Function. Proceedings of the 7th International Conference on Theory and Practice of Electronic Governance (ICEGOV 2013). (2013), 32-41.

[24] Medjahed, B. et al. 2003. Composing Web Services on the Semantic Web. The International Journal on Very Large Data Bases. 12, 4 (2003), 333-351.

[25] Medjahed, B. et al. 2005. Customized delivery of egovernment Web services. Intelligent Systems, IEEE. 20, 6 (2005), 77-84.

[26] Noy, N.F. and McGuinness, D.L. 2001. Ontology development 101: A guide to creating your first ontology. 
[27] Ojo, A. et al. 2007. A Composite Domain Framework for Developing Electronic Public Services. In proceedings of the International Conference on Software Engineering Theory and Practice (SETP 2007), Orlando, Florida, USA, July 2007. (2007).

[28] Penadés, M.C. et al. 2014. Product Line-based customization of e-Government documents. CEUR Workshop Proceedings.

[29] Rincón, L.F. et al. 2014. An Ontological Rule-Based Approach for Analyzing Dead and False Optional Features in Feature Models. Electronic Notes in Theoretical Computer Science. 302, (2014), 111-132.

[30] Stadlhofer, B. et al. 2009. Ontology Driven e-
Government. Electronic Journal of e-Government. 7, 4 (2009), 415-424.

[31] Tautz, C. and Gresse von Wangenheim, C. 1998 REFSENO: A Representation Formalism for Software Engineering Ontologies.

[32] Transport Operator License - Guidelines and Forms: https://www.rtol.ie/rtol-online/forms. Accessed: 2011-0520.

[33] UNEP 2012. Sustainable, Resource Efficient Cities Making it Happen!

[34] United Nations 2014. World Urbanization Prospects: The 2014 Revision, Highlights. 